\title{
Factors that Influence Financial Leverage of Small Business Firms in India
}

\author{
Amarjit Singh Gill (Corresponding author) \\ College of Business Administration \\ Trident University International \\ 5757 Plaza Drive, CA, 90630, USA \\ E-mail: agill@tuiu.edu \\ Harvinder Singh Mand \\ Sikh National College, Banga \\ District Sahid Bhagat Singh Nagar, Pin Code: 144505, East Punjab, India \\ E-mail: hsmand27@gmail.com
}

Suraj P. Sharma

GTB National College, Dakha

District Ludhiana, Pin Code: 141102, East Punjab, India

E-mail:sps07@rediffmail.com

Neil Mathur

School of Business Administration

Simon Fraser University

515 W. Hastings Street, Vancouver, BC, V6B-5K3, Canada

E-mail: nmathur@sfu.ca

$\begin{aligned} & \text { Received: November 16, } 2011 \quad \text { Accepted: December 26, } 2011 \quad \text { Published: March 1, } 2012 \\ & \text { doi:10.5539/ijef.v4n3p33 }\end{aligned}$ URL: http://dx.doi.org/10.5539/ijef.v4n3p33

\begin{abstract}
The purpose of this study is to examine the factors that influence financial leverage of small business firms in India. This study also seeks to extend the findings of Michaelas et al. (1999). Small business owners from Punjab area of India were surveyed in order to gather information. Subjects were asked about their perceptions, beliefs, and feelings regarding the factors that influence financial leverage of their firms. This study utilized survey research (a non-experimental field study design). The findings of this paper show that small business growth, small business performance, total assets, sales, tax, and family have positive influence on the financial leverage of small business firms in India. This study contributes to the literature on the factors that influence financial leverage of small business firms. The findings may be useful for the financial managers, investors, and financial management consultants.
\end{abstract}

Keywords: Financial leverage, Small business growth, Small business performance, Tax

\section{Introduction}

The purpose of this study is to examine the factors that influence financial leverage of small business firms in India. One of the tough challenges that business firms face is the choice of capital structure. Capital structure decision is important because it affects the financial performance of the small business firms. Abor (2005) defines capital structure as specific mix of debt and equity that a firm uses to finance its operations. Although small business firms have options to choose among many alternative capital structures, they tend to rely on borrowings from financial institutions such as banks. The decision to finance with debt rather than equity may be driven by necessity instead of choice because small business firms do not have the same access to capital that larger public firms do. Small 
business firms cannot issue publicly-held debt or equity because of their small size and the high cost of issuing securities. As a result, small business firms tend to rely on bank financing and trade credits (Petersen \& Rajan, 1994). In addition, small business firms that are relatively new and lack a consistent track record of profitability face difficulties in demonstrating their capacity to repay a loan and to provide collateral. Asymmetric and/or incomplete information between the borrower and the lender also represents a potential financing problem for small privately-held firms (Ang, 1992; Petersen \& Rajan, 1994).

Modigliani and Miller (1958) were the first authors who developed capital structure theory. Since then, many researcher followed Modigliani and Miller's path to develop new theory on debt policy of firms. While in some theories, the existence of taxes and bankruptcy costs makes debt relevant (DeAngelo \& Masulis, 1980), in other theories the relevance is due to information asymmetry; that is, managers have information that investors do not have (Myers, 1984; Ross, 1977). A third relevant theory is agency theory advanced by Jensen and Meckling (1976), which is derived from the conflict between corporate managers, outside stockholders, and bondholders. However, the empirical evidence regarding the alternative theories is still inconclusive (Rajan \& Zingales, 1995).

The general result from the various capital structure studies is that the combination of leverage related costs and the tax advantage of debt, produces an optimal capital structure below $100 \%$ debt financing, as the tax advantage is traded against the likelihood of incurring bankruptcy costs (Michaelas et al., 1999, p. 113). The determinants of capital structure have been debated for many years and still represent one of the main unsolved issues in the corporate finance literature. Many theoretical studies and much empirical research have addressed these issues, but there is not yet a fully supported and unanimously accepted theory (Morri \& Beretta, 2008). Indeed, what makes the capital structure debate so exciting is that only a few of the developed theories have been tested by empirical studies and the theories themselves lead to different, not mutually exclusive and sometimes opposed, results and conclusions (Gill et al., 2009, p. 48).

Small business firms face different issues from larger publically traded firms because of different complexities such as shorter expected life, presence of estate tax, intergenerational transfer problems, and prevalence of implicit contracts. The problems like agency and asymmetric information are more complex in the small business industry (Ang, 1992). Nevertheless, there has not been much research conducted on small, growing, entrepreneurial companies, and the factors affecting the financial leverage of these firms. The capital structure of small business firms is a major area of policy concern, and much of the work, particularly on the failure of small firms, has identified financial leverage as a major cause of decline (Lowe et al., 1991; Michaelas et al., 1999, p. 114).

Most other empirical studies on the debt policy of the firm were conducted on publically traded industrial firms. Therefore, this study examines the factors that influence financial leverage of small business firms that are not listed on the stock exchanges. A variety of variables that are potentially responsible for determining financial leverage of the firm can be found in the literature. In this study, the selection of exploratory variables is based on the alternative capital structure theories and previous empirical work. The choice is sometimes limited, however, because of lack of relevant data. As a result, the final set of proxy variables includes 10 factors: small business growth, small business performance, long-term assets, current assets, total assets, sales, tax, family, industry, and financial leverage.

\section{Literature Review}

The capital structure theory of Modigliani and Miller (1958) indicates that firms select the mix of debt and equity to minimize weighted average cost of capital (WACC). Because interest expense is tax deductible, debt is less costly than equity as a source of capital. Therefore, firms maintain a certain level of debt in the capital structure to minimize cost of capital, which in turn, helps to maximize the value of the firm. Other researchers, however, have suggested alternatives to Modigiliani and Miller's theory of capital structure. For example, Timmons (1994) observed that capital requirements are different at different stages of firm growth. Small and young firms may draw capital from internal sources such as family and friends. As the successful firm grows, more capital is required to finance growth, and the firm typically needs at some point to turn to external sources such as banks and the public debt and equity markets (Coleman \& Cohn, 1999, p. 3). Myers (1984) refers this to a "pecking order." The peaking order is a theory of finance stating that firms use internally generated funds in the form of retained earnings before turning to external sources. When retained earnings are not enough, firms first seek out sources of debt before they use more costly external equity.

Financial economists have advanced a number of leverage relevance theories by relaxing the perfect capital market assumption of Modigliani and Miller. Now, approximately 55 years later, the theory of capital structure is extensive and can be classified into four categories: i) tax-based theories, ii) agency cost theories, iii) asymmetric information, and iv) signalling theories. These market imperfections have been brought forward as determinants of capital structure, which refer to the costs and benefits associated with financial contracting. However, these theories make 
no distinction between small and large firms (Michaelas et al., 1999). Ang (1991) also states that the theory of finance was not developed with the small business firms in mind.

Corporate income tax has an important impact on debt-equity choices. Although, the tax shield proposition of Modigliani and Miller (1958) suggest that the firms facing higher marginal tax rates should use higher debts, Biger et al. (2008) argue that tax shield proposition does not apply if firms have interest free liabilities. Biger et al. may be correct because small business owners in India sometimes borrow interest free money from family members and friends.

DeAngelo and Masulis (1980) assert that as debt interest shields income from taxation, profitable firms with few non-debt tax shields use more debt than less profitable firms. In practice, however, firms do not follow this policy. Michaelas et al. (1999, p. 114) describe that many small firms do not use any debt. This may be because smaller firms make less profit than the larger firms. Another reason for using low debt or no debt is that the potential of bankruptcy is high for the small firms if they increase the level financial leverage. In addition, small firms face lower marginal tax rates than the larger firms and get lower tax benefits.

Myers (1977) describe that short-term debt is in the favor of the firm because it can mitigate agency problem and minimize agency costs which incur from the conflict of interest between shareholders and bondholders. Michaelas $e t$ al. (1999) also point out that Myers' (1977) proposition is more applicable in the small business context where the trade-off between independence and availability of finance is likely to be highlighted and where much debt is of a short-term nature.

The agency problems can be serious when i) the level of asymmetric information is greater, ii) the agent has the capacity and incentive to affect wealth transfers between parties and the corporate contract, and iii) the agent's partial ownership allows him to consume firm's assets while paying less than the sum of the individual costs to the firm's principals (Barnea et al., 1981). As a result one can expect agency costs to be higher in smaller firms as a small business owner/manager is likely to put his own and his venture's interest first, especially in the early years when survival is at stake (Michaelas et al., 1999). However, availability of collateral for debt minimizes these costs. Banks respond to both adverse selection and moral hazard by seeking collaterals (Stiglitz \& Weiss, 1981). It is common for lenders to require collaterals for business loans to mitigate default risk. Therefore, it can be expected that firms which possess fixed assets with a high collateral value will have easier access to external finance and probably a higher level of debt in their capital structure relative to firms with lower levels of collateralizable assets (Michaelas et al., 1999, p. 115).

The debt policy is designed to mitigate inefficiencies in the investment decisions of firms that are caused by the information asymmetry between managers (insiders) and creditors (outsiders) (Myers, 1984). Pettit and Singer (1985) also explain that problems of asymmetric information and agency costs affect the availability of credit for small businesses. Therefore, small business firms that have low level of collateral rely on the profitability of the firm for further financing.

Firm size also influences the financial leverage of the firm. Michaelas et al. (1999, p. 116) argue that small businesses carry less debt than the larger firms due to generally i) lower marginal corporate tax rates for very small firms, ii) higher bankruptcy costs, iii) greater agency costs, and iv) greater costs of resolving the larger informational asymmetries.

The empirical studies on the factors that influence the financial leverage of the firm are as follows:

Michaelas et al. (1999) gathered data from the Lotus One-Source Database of UK small firms and found positive relationships between i) non-debt tax shield and long-term debt, ii) firm growth and debt, iii) asset structure and debt, and iv) firm size and debt. Authors also found that level of debt is negatively correlated with profitability.

Gordon and Lee (1999) used "US Statistics of Income" balance sheet data on all corporations to compare the debt policies of firms of different sizes and found that taxes have a strong effect on debt levels of small firms.

Esperanca et al. (2003) used the Portuguese Central Bank (Banco de Portugal) to collect 995 small manufacturing firms' data between 1992 and 1996. Authors found that leverage is positively correlated with i) firm size, asset composition, and firm growth and ii) negatively correlated with firm's profitability.

Huang and Song (2006) collected data from more than 1000 Chinese listed companies up to the year 2000 and found that leverage increases with firm size, non-debt tax shields and fixed assets, and decreases with profitability.

Sayılgan et al. (2006) took a sample of 123 Turkish manufacturing firms listed on the Istanbul Stock Exchange (ISE) from 1993-2002. Their analysis shows that leverage ratio is i) positively correlated with firm size and firm growth and ii) negatively correlated with profitability and non-tax debt shield. 
Eldomiaty (2007) used 99 firms from 14 non-financial industries and found a positive relationship between firm growth and debt.

Gill et al. (2009) collected data from 158 American service firms. Through regression analysis, Gill et al. found that leverage is negatively correlated with collateralized assets and firm's profitability.

Gill and Mathur (2011) took a sample of 166 Canadian firms listed on the Toronto Stock Exchange for a period of 3 years (from 2008-2010). Through regression analysis, they found that financial leverage is i) positively affected by firm size and ii) negatively affected by collateralized assets, effective tax rate, firm performance, and firm growth.

In summary, literature review shows that tax shield, asset structure, firm size, firm growth, firm performance, and collateralized assets influence the financial leverage of the firm.

\section{Methods}

\subsection{Measurement}

In order to remain (for comparison and reference reasons) consistent with previous research, the measures were taken from three referent studies, which in turn, are based on previous studies in behavioral finance. All measures pertaining to:

i) Small business growth and small business performance were taken from Zehir et al. (2006),

ii) Measures pertaining to financial leverage were taken from Beattie et al. (2006), and

iii) Measures pertaining to assets, sales, and tax were taken from Michaelas et al. (1999).

All the scale items were be reworded to apply to Indian small business owners and the reliability of these re-worded items was re-tested. Respondents were asked to indicate their agreement with each item, using a five-point Likert scale ranging from "Strongly Disagree" to "Strongly Agree."

Small business growth (SBG) independent variable is operationalized as the extent to which small business owners perceive that the overall growth of their small businesses has improved over the last three years. Zehir et al. (2006) used the seven-item tolerance-of-freedom scale which measures the "SBG" variable. Two items were selected to measure the "SBG" variable. Scale items were reworded and the reliability of these re-worded items was re-tested.

The Cronbach alpha on the responses of the 29 small business owners who participated in the pre-test of the above scale items was 0.95. All two items were included in the final questionnaire.

Small business performance (SBP) independent variable is operationalized as the extent to which small business owners perceive that the net profit margin, return on assets, and return on invested capital have improved over the last three years. Zehir et al. (2006) used the seven-item tolerance-of-freedom scale which measures the "small business growth" variable. In the present study only three items were selected to measure the "SBP" variable. Scale items were reworded and the reliability of these re-worded items was re-tested.

The Cronbach alpha on the responses of the 29 small business owners who participated in the pre-test of the above scale items was 0.91. All three items were included in the final questionnaire.

Financial leverage (FL) dependent variable is operationalized as the extent to which small business owners perceive that they maintain a level of leverage that i) maximizes tax advantage of interest deductions, ii) improves company performance, iii) maximizes cash inflows, iv) minimizes chances of bankruptcy, v) indicates long-term survival, and vi) prevents takeovers. Beattie et al. (2006) used thirteen-items which measures appropriate amount of debt. Six items were selected to measure the "FL" variable. Scale items were reworded and the reliability of these re-worded items was re-tested.

The Cronbach alpha on the responses of the 29 small business owners who participated in the pre-test of the above scale items was 0.94. All six items were included in the final questionnaire.

Long-term assets (LA) control variable was measured by a single item that asked respondents to describe if long-term assets (e.g., building, automobiles, tools, etc.) of their companies increased within last three years. Categorized alternative responses were: 1) Yes and 0) No.

Current assets (CA) control variable was measured by a single item that asked respondents to describe if current assets (e.g., inventory, accounts receivables, cash, etc.) of their companies increased within last three years. Categorized alternative responses were: 1) Yes and 0) No.

Total assets (TA) control variable was measured by a single item that asked respondents to describe if total assets of their companies increased within last three years. Categorized alternative responses were: 1) Yes and 0) No. 
Sales (SALES) control variable was measured by a single item that asked respondents to describe if average sales of their companies increased within last three years. Categorized alternative responses were: 1) Yes and 0) No.

Tax (TAX) control variable was measured by a single item that asked respondents to describe if average tax of their companies increased within last three years. Categorized alternative responses were: 1) Yes and 0) No.

Family and industry were also used as control variables.

Family (FAMILY) control variable was measured by a single item that asked respondents to indicate their family characteristics. Categorized alternative responses were: 0) Single Family (1-5 Family Members) and i) Joint Family (6 Family Members and More).

Industry (IND) control variable was measured by a single item that asked respondents to indicate the names of the sectors in which their small businesses operate. Categorized alternative responses were: 0) Service and i) Manufacturing.

\subsection{Sampling Frame, Questionnaire Distribution, and Collection}

The current study consisted of the population of Indian small business owners. Indian small business owners living in Punjab (Ludhiana, Malerkotla, Raikot, Banga, Hoshiar Pur, Kaputhala, Phagwara, Jalandhar, and Sahid Bhagat Singh Nagar) area of India were chosen as a sampling frame.

\subsection{Sampling Method, Sampling Issues, and Possible Planned Solutions}

Punjab (Ludhiana, Malerkotla, Raikot, Banga, Hoshiar Pur, Kaputhala, Phagwara, Jalandhar, and Sahid Bhagat Singh Nagar) area of India was chosen as the research site to collect data. Given that the population is "abstract" [e.g., it was not possible to obtain a list of all members of the focal population] (Huck, 2008, p. 101), a non-probability (purposive) sample was obtained. In a purposive sample, participants are screened for inclusion based on criteria associated with members of the focal population. The focal population was comprised of small business owners in the Punjab area of India. The survey did not need to be translated into Punjabi or Hindi for the Indian participants since almost all the small business owners can read and write English. Researchers were also available for translation. The instruction sheet indicated that participants could contact the researchers by telephone and/or email regarding any questions or concerns they might have about the research.

To avoid sampling bias, data collection team was asked to only choose participants that represent the target population. Non-Indian small business owners were excluded.

To achieve a convenience sample, an exhaustive list of Indian small business owners' names and telephone numbers were created to distribute surveys and to conduct telephone interviews. Survey questionnaire bundles coupled with an instruction sheet were provided to the surveyors for distribution.

The sample included approximately 800 research participants encompassing Indian small business owners. A total of 209 surveys were completed over the telephone (approximately 10\% of the surveys were completed over the telephone), through personal visits, and received by mail. Two of the surveys were non-usable. The response rate was roughly $26.12 \%$. The remaining cases were assumed to be similar to the selected research participants.

\subsection{Issues Related to Confidentiality of the Research Participants}

All individuals who were approached were ensured that their names will not be disclosed and confidentiality will be strictly maintained. In addition all subjects were requested NOT to disclose their names on the questionnaire. Since the research was based on the survey questionnaire small business owners were not forced to respond to each specific question.

All subjects were provided with stamped envelopes and confidentiality was ensured. There was no obligation for the subjects to answer our questions over the telephone and in person. Before any telephone interview the person was asked for willingness to participate and of course no one was forced to participate.

Small business owners' Consent Letter specifically indicated that by completing the survey, subjects have consented to participate in the study. Any information that was obtained in connection with this study and that can be identified with subjects will remain confidential and will be disclosed only with subjects' permission or as required by law.

\section{Analysis and Results}

Table 1 shows descriptive statistics related to this study. The information related to industry control variable is as follows:

Responses from manufacturing industry $=67$

Responses from service industry $=140$ 
Measures of central tendency, variance, skewness, and kurtosis were calculated on responses to all of the items. Skewness measures for all of the items were within the range of: -0.776 to -1.382 , which is considered to be a good range for most research that requires using statistics appropriate to normal distributions. Therefore, we used statistics that assume scalar values and symmetric distributions to test our hypotheses.

We began our analysis by factor analyzing responses to the 11 items that described the respondents' feelings about their small business growth, small business performance, and financial leverage. The principle components analysis (a cluster analysis tool designed to capture the variance in a dataset in terms of principle components) with number of factors set to 3 and a varimax rotation explained $81.49 \%$ of the variance in the original scores (see Table 2). As can be seen in Table 3, all the items loaded on the expected factors.

Cronbach Alpha on the clusters of items: SBG 0.842; SBP 0.907; and FL 0.944.

The question subsets were analyzed in order to enable the calculation of the weighted factor scores. In terms of these weighted factor score items: two SBG, three SBP, and six FL, loaded approximately equally.

Table 4 provides the Pearson correlation for the variables used in the regression model. The findings are as follows:

Overall, financial leverage is positively correlated with small business growth (SBG), small business performance (SBP), long-term assets (LA), total assets (TA), sales (SALES), tax (TAX), and family (FAMILY). The financial leverage is positively correlated with SBG, SBP, LA, current assets (CA), TA, SALES, and TAX in the Indian manufacturing industry. The financial leverage is positively correlated with SBG, SBP, TA, SALES, TAX, and FAMILY in the Indian services industry (see Table 4).

\subsection{Testing of Hypotheses}

In this section, we present the empirical findings on the relationships between SBG, SBP, LA, CA, TA, SALES, TAX, FAMILY, industry (IND), and financial leverage (FL) of small business firms.

Positive relationships between i) SBG and FL, ii) SBP and FL, iii) TA and FL, iv) SALES and FL, v) TAX and FL, vi) FAMILY and FL, and vii) IND and FL were found (see Table 5); that is, SBG, SBP, TA, SALES, TAX, FAMILY, and IND are the predictors of financial leverage of small business firms in India.

Non-significant relationships between i) LA and FL and ii) CA and FL were found (see Table 5); that is, LA and CA are not the predictors of financial leverage of small business firms in India.

In studying our results, we noted that the size of the sample (with a predominance of small business owners from service industry -140 responses from service industry and 67 responses from manufacturing industry), might affect the results. We first tested to see if SBG, SBP, LA, CA, TA, SALES, TAX, FAMILY, and FL were significantly different between small business firms from manufacturing and service industries. Using one-way ANOVAs, we found that perceived:

i) SBG did not differ between the 2 types of small business firms (sig. $=0.952$ ),

ii) SBP did not differ between the 2 types of small business firms (sig. $=0.472$ ),

iii) LA did not differ between the 2 types of small business firms (sig. $=0.400$ ),

iv) CA did not differ between the 2 types of small business firms (sig. $=0.595$ ),

v) TA did not differ between the 2 types of small business firms (sig. $=0.403$ ),

vi) SALES characteristics did differ between the 2 types of small business firms (sig. $=0.006$ ),

vii) TAX did not differ between the 2 types of small business firms (sig. $=0.655$ ),

viii) FAMILY did differ between the 2 types of small business firms (sig. $=0.000)$, and

ix) FL did differ between the 2 types of small business firms (sig. $=0.082$ ).

We re-tested the hypotheses for subsets of the sample.

Positive relationships between i) SBG and FL, ii) SBP and FL, iii) TA and FL, and iv) SALES and FL were found (see Table 5); that is, SBG, SBP, TA, and SALES are the predictors of financial leverage of small business firms in the manufacturing industry of India.

Non-significant relationships between i) LA and FL, ii) CA and FL, iii) TAX and FL, and iv) FAMILY and FL, were found (see Table 5); that is, LA, CA, TAX, and FAMILY are not the predictors of financial leverage of small business firms in the manufacturing industry of India.

Positive relationships between i) SBG and FL and ii) FAMILY and FL were found (see Table 5); that is, SBG and FAMILY are the predictors of financial leverage of small business firms in the service industry of India. 
Non-significant relationships between i) SBP and FL, ii) LA and FL, iii) CA and FL, iv) TA and FL, v) SALES and FL, and vi) TAX and FL were found (see Table 5); that is, SBP, LA, CA, TA, SALES, and TAX are not the predictors of financial leverage of small business firms in the service industry of India.

Note that:

- A test for multicollinearity was performed. All the variance inflation factor (VIF) coefficients are less than 4 and tolerance coefficients are greater than 0.27 .

- $43.3 \%\left(\mathrm{R}^{2}=0.433\right)$ of the variance in the degree of FL can be explained by the degree of IND, SBG, CA, LA, FAMILY, SALES, TAX, TA, and SBP,

- $76.3 \%\left(\mathrm{R}^{2}=0.763\right)$ of the variance in the degree of FL can be explained by the degree of FAMILY, TA, CA, SALES, TAX, LA, SBG, and SBP in the manufacturing industry, and

- $35.1 \%\left(\mathrm{R}^{2}=0.351\right)$ of the variance in the degree of FL can be explained by the degree of FAMILY, CA, SALES, LA, SBG, TAX, TA, and SBP in the service industry.

As shown in Table 5, analysis of variance (ANOVA) tests are also significant at 0.000 .

\section{Discussion, Implications, and Future Research}

\subsection{Discussion}

The main purpose of this study was to examine the perceived factors that influence financial leverage of small business firms in India. This was done by surveying a sample of small business owner from Punjab area of India.

Overall findings show positive relationships between i) SBG and FL, ii) SBP and FL, iii) TA and FL, iv) SALES and FL, v) TAX and FL, vi) FAMILY and FL, and vii) IND and FL. The results also show positive relationships between i) SBG and FL, ii) SBP and FL, iii) TA and FL, and iv) SALES and FL in the manufacturing industry of India. In addition, the findings show positive relationships between i) SBG and FL and ii) FAMILY and FL in the service industry of India (see Table 5). These results lend some support to the findings of:

i) Michaelas et al. (1999) who found positive relationships between i) non-debt tax shield and long-term debt, ii) firm growth and debt, iii) asset structure and debt, and iv) firm size and debt.

ii) Gordon and Lee (1999) who found that taxes have a strong effect on debt levels of small firms.

iii) Esperanca et al. (2003) who found that leverage is positively related to firm size, asset composition, and firm growth.

iv) Huang and Song (2006) who found that leverage increases with firm size, non-debt tax shields, and fixed assets.

v) Sayılgan et al. (2006) who found that leverage ratio is positively related to firm size and firm growth.

vi) Eldomiaty (2007) who found a positive relationship between firm growth and debt.

vii) Gill and Mathur (2011) who found that financial leverage is positively affected by firm size.

The results of this study contradict with the findings of:

i) Esperanca et al. (2003) and Huang and Song (2006) who found that leverage decreases with profitability.

ii) Sayılgan et al. (2006) who found that leverage ratio is negatively related to profitability and non-tax debt shield.

iii) Gill et al. (2009) who found that leverage is negatively correlated with collateralized assets and firm's profitability.

iv) Gill and Mathur (2011) who found that financial leverage is negatively affected by collateralized assets, effective tax rate, firm performance, and firm growth.

The different results may be because the above studies are related to larger firms from different countries. Table 6 shows the summery of previous authors' findings related to the factors that influence financial leverage of the firm.

Although, financial leverage tends to increase with SBG, SBP, TA, and SALES in the manufacturing industry, this is not the case in the service industry of India. In the service industry, financial leverage tends to increase with the small business growth and family support. This may be because small business firms tend to rely on the family support and small business growth. For example, in the joint family businesses, all the income is kept together. It is important to note that majority of small businesses (service and manufacturing) in India are running as family businesses. Although family business may not show profitability, family members get paid in the form of salary. The financial leverage is different for service and manufacturing industries. 
In conclusion, SBG, SBP, LA, CA, TA, SALES, TAX, FAMILY, and IND influence the financial leverage of small business firms in India.

\subsection{Limitations}

The present study asks for responses from fixed format, set-questions survey tools, which could direct questions to the exclusion of providing additional input. A mail/drop off survey data collection method contributed to a low response rate or response error. Some favorable techniques such as including postage paid mail, sending a cover letter, providing a deadline for returning the survey, and promising anonymity were applied in order to increase the response rate. Maturation of participants can also affect the survey response rate. Maturation of participants, in the context of this research, means that some of the research participants may be on holidays. However, a short study period (four weeks) limited any negative effects from maturation.

\subsection{Future Research}

The present study is limited to perceptions and intentions. The relations found may suffer from common factor bias, as the questions were parts of the same data collection instrument. Future research is needed to test the relation of financial leverage to actual future growth through longitudinal data. Personal characteristics of the small business owners also need further study in India.

\section{References}

Abor, J. (2005). The effect of capital structure on profitability: Empirical analysis of listed firms in Ghana. Journal of Risk Finance, 6(5), 438-45, d http://dx.doi.org/10.1108/15265940510633505.

Ang, J.S. (1991). Small business uniqueness and the theory of financial management. Journal of Small Business Finance, 1(1), 1-13.

Ang, J.S. (1992). On the theory of finance for privately held firms. Journal of Small Business Finance, 1(3), 185-203.

Barnea, A., Haugen, R.H., \& Senbet, L.W. (1981). An equilibrium analysis of debt financing under costly tax arbitrage and agency problems. Journal of Finance, 36(3), 569-581, http://dx.doi.org/10.2307/2327519.

Beattie, V., Goodacre, A., \& Thomson, S.J. (2006). Corporate financing decisions: UK survey evidence. Journal of Business Finance and Accounting, 33(9/10), 1402-1434, http://dx.doi.org/10.1111/j.1468-5957.2006.00640.x.

Biger, N. Nguyen, N.V., \& Hoang, Q.X. (2008). The Determinants of Capital Structure: Evidence from Vietnam. International Finance Review, 8, 307-326, http://dx.doi.org/10.1016/S1569-3767(07)00015-5, http://www.emeraldinsight.com/books.htm?chapterid=1758076\&show=pdf.

Coleman, S., \& Cohn, R. (1999). Small firm use of leverage: A comparison of men and women-owned firms. Conference Proceedings, United States Association for Small Business and Entrepreneurship, San Diego, January
14-17.
[Online]
Available:

[https://usasbe.org/knowledge/proceedings/proceedingsDocs/USASBE1999proceedings-coleman.pdf] (November 13, 2011)

DeAngelo, H., \& Masulis, R. (1980). Optimal capital structure under corporate and personal taxation. Journal of Financial Economics, Vol. 8, No. 1, p.p. 3-29, , http://dx.doi.org/10.1016/0304-405X(80)90019-7.

Eldomiaty, T.I. (2007). Determinants of corporate capital structure: evidence from an emerging economy. International Journal of Commerce \& Management, 17(1/2), 25-43, http://dx.doi.org/10.1108/10569210710774730.

Esperanca, J.P., Gama, A.P., \& Gulamhussen, M.A. (2003). Corporate debt policy of small firms: an empirical (re)examination. Journal of Small Business and Enterprise Development, 10(1), 62-80, http://dx.doi.org/10.1108/14626000310461213.

Gill, A., Biger, N., Pai, C., \& Bhutani, S. (2009). The determinants of capital structure in the service industry: evidence

from United States. The Open Business journal, 2, 48-53, http://dx.doi.org/10.2174/1874915100902010048.

Gill, A. \& Mathur, N. (2011). Factors that influence financial leverage of Canadian firms. Journal of Applied Finance and Banking, 1(2), 19-37.

Gordon, R.H., \& Lee, Y. (1999). Do taxes affect corporate debt policy? Evidence from U.S. corporate tax return data. Journal of Public Economics, 82(2), 195-224, http://dx.doi.org/10.1016/S0047-2727(00)00151-1. 
Huang, S.G., \& Song, F.M. (2001). The determinants of capital structure: Evidence from China. School of Economics and Finance and Center for China Financial Research, The University of Hong Kong Press for SSRN, 1-35. [Online] Available: http://papers.ssrn.com/sol3/papers.cfm?abstract_id=320088 (November 20, 2011)

Huck, S.W. (2008). Reading Statistics and Research, 5th Edition. Pearson Educational Inc., Allyn and Bacon, Boston - New York.

Jensen, M., \& Meckling, W. (1976). Theory of the firm: managerial behaviour, agency costs and ownership structure. Journal of Financial Economics, 3, 305-60.

Lowe, J., Tibbits, G.E., \& McKenna, J. (1991). Small firm growth \& failure: Public policy issues and practical problems. In

Renfrew, K.M., \& R.C. McCosker. (eds.). The Growing Small Business, Proceedings of Fifth National Small Business Conference, 175-190.

Michaelas, N., Chittenden, F., \& Poutziouris, P. (1999). Financial policy and capital structure choice in U.K. SMEs: Empirical evidence from company panel data. Small Business Economics, 12(2), 113-130.

Modigliani, F., \& Miller, M. (1958). The cost of capital, corporation finance and the theory of investment. The American Economic Review, 48(3), 261-97.

Morri, G., \& Beretta, C. (2008). The capital structure determinants of REITs. Is it a peculiar industry? Journal of European Real Estate Research, 1(1), 6-57, http://dx.doi.org/10.1108/17539260810891488.

Myers, S.C. (1977). Determinants of corporate borrowing. Journal of Financial Economies, 9, 147-76, http://dx.doi.org/10.1016/0304-405X(77)90015-0.

Myers, S.C. (1984). The capital structure puzzle. Journal of Finance, 39, 575-92, http://dx.doi.org/10.2307/2327916.

Petersen, M.A., \& Rajan, R.G. (1994). The benefits of lending relationships: evidence from small business data. The Journal of Finance, 49, 3-37, http://dx.doi.org/10.2307/2329133.

Pettit, R., \& Singer, R. (1985). Small business finance: A research agenda. Financial Management (Autumn), 47-60, http://dx.doi.org/10.2307/3665059.

Rajan, R.G., \& Zingales, L. (1995). What do we know about the capital structure? Some evidence from international data. Journal of Finance, 50, 1421-1460, http://dx.doi.org/10.2307/2329322.

Ross, G.C. (1977). The determination of financial structure: The incentive signalling approach. Bell Journal of Economics \& Management Science, 8(1), 23-40, http://dx.doi.org/10.2307/3003485.

Sayılgan, G., Karabacak, K., \& Küçükkocao, G. (2006). The firm-specific determinants of corporate capital structure: Evidence from Turkish panel data. Investment Management and Financial Innovations, 3(3), 125-139.

Stiglitz, J.E., \& Weiss, A. (1981). Credit rationing in markets with imperfect information. American Economic Review, 71(3), 393-410.

Timmons, J.A. (1994). New venture creation. Chicago: Irwin.

Zehir, C., Acar, A.Z., \& Tanriverdi, H. (2006). Identifying organizational capabilities as predictors of growth and business performance. The Business Review, 5(2), 109-116. 
Table 1.

Min $=$ Minimum

$\overline{\mathrm{x}}=$ Mean

$\mathrm{SBG}=$ Small business growth

$\mathrm{FL}=$ Financial leverage

\begin{tabular}{|l|r|r|r|c|}
\cline { 2 - 5 } \multicolumn{1}{c|}{} & \multicolumn{4}{c|}{ Descriptive Statistics } \\
\cline { 2 - 5 } \multicolumn{1}{c|}{} & \multicolumn{1}{c|}{ Min } & \multicolumn{1}{c|}{ Max } & \multicolumn{1}{c|}{$\overline{\mathrm{x}}$} & \multicolumn{1}{c|}{$\sigma$} \\
\hline SBG & & & & \\
\hline Sales growth over last three years & 1 & 5 & 3.85 & 0.978 \\
\hline Market share growth over three years & 1 & 5 & 3.60 & 0.944 \\
\hline & & & & \\
\hline SBP & 1 & & & \\
\hline Net profit margin growth over last three years & 1 & 5 & 3.92 & 0.987 \\
\hline Return on assets growth over last three years & 1 & 5.74 & 0.995 \\
\hline Return on invested capital over last three years & 1 & 5 & 3.67 & 0.930 \\
\hline & & & & \\
\hline FL & & & & \\
\hline Maintaining a level of financial leverage that: & 1 & 5 & 3.99 & 0.900 \\
\hline Maximizes tax advantage of interest deductions & 1 & 5 & 3.82 & 0.895 \\
\hline Improves company performance & 1 & 5 & 3.88 & 0.917 \\
\hline Maximizes cash inflows & 1 & 5 & 3.90 & 0.916 \\
\hline Minimizes chances of bankruptcy & 1 & 5 & 3.77 & 0.963 \\
\hline Indicates long-term survival & 1 & 5 & 3.99 & 0.900 \\
\hline Prevents takeovers & 1 & 5 & 3.91 & 0.863 \\
\hline
\end{tabular}

Max = Maximum

$\sigma=$ Standard Deviation

$\mathrm{SBP}=$ Small business performance

Table 2.

\begin{tabular}{|c|c|r|r|}
\hline Total Variance Explained - Rotation Sums of Square Loadings \\
\hline & \multicolumn{3}{|c|}{ Total Variance Explained } \\
\hline & \multicolumn{3}{|c|}{ Rotation Sums of Squared Loadings } \\
\hline Component & Total & \% of Variance & Cumulative \% \\
\hline 1 & 4.577 & 41.611 & 41.611 \\
\hline 2 & 2.674 & 24.311 & 65.921 \\
\hline 3 & 1.713 & 15.573 & 81.495 \\
\hline
\end{tabular}

Extraction Method: Principal Component Analysis.

Table 3.

\begin{tabular}{|c|c|c|c|}
\hline & \multicolumn{3}{|c|}{ Rotated Component Matrix $^{a}$} \\
\hline & \multicolumn{3}{|c|}{ Component } \\
\hline & 1 & 2 & 3 \\
\hline SBG1) Sales of my company has gone up over the last three years. & 0.270 & 0.397 & $\mathbf{0 . 7 8 6}$ \\
\hline SBG2) Market share of my company has gone up over the last three years. & 0.225 & 0.329 & 0.850 \\
\hline SBP1) The net profit margin of my company has gone up over the last three years. & 0.238 & 0.848 & 0.259 \\
\hline SBP2) The return on assets of my company has gone up over the last three years. & 0.240 & 0.846 & 0.249 \\
\hline SBP3) The return on invested capital has gone up over the last three years. & 0.249 & 0.848 & 0.270 \\
\hline \multicolumn{4}{|l|}{ I maintain a level of leverage that...: } \\
\hline DF1) ... Maximizes tax advantage of interest deductions. & 0.857 & 0.223 & 0.197 \\
\hline DF2) ... Improves company performance. & 0.858 & 0.183 & 0.146 \\
\hline DF3) ... Maximizes cash inflows. & 0.837 & 0.161 & 0.187 \\
\hline DF4) ... Minimizes chances of bankruptcy. & 0.846 & 0.215 & 0.169 \\
\hline DF5) ... Indicates long-term survival. & 0.838 & 0.225 & 0.133 \\
\hline DF6) ... Prevents takeovers. & 0.830 & 0.221 & 0.170 \\
\hline
\end{tabular}


Table 4.

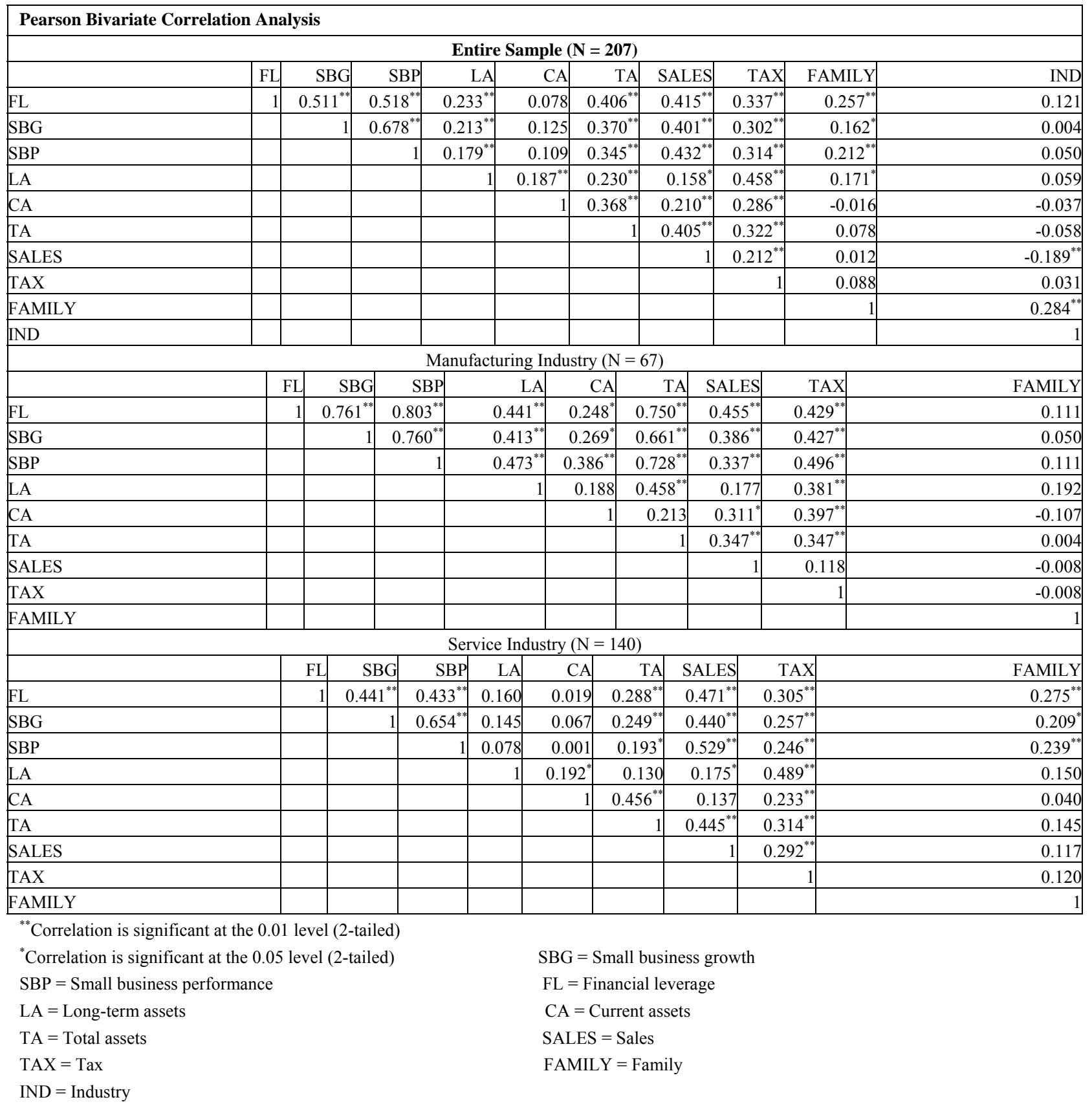


Table 5 .

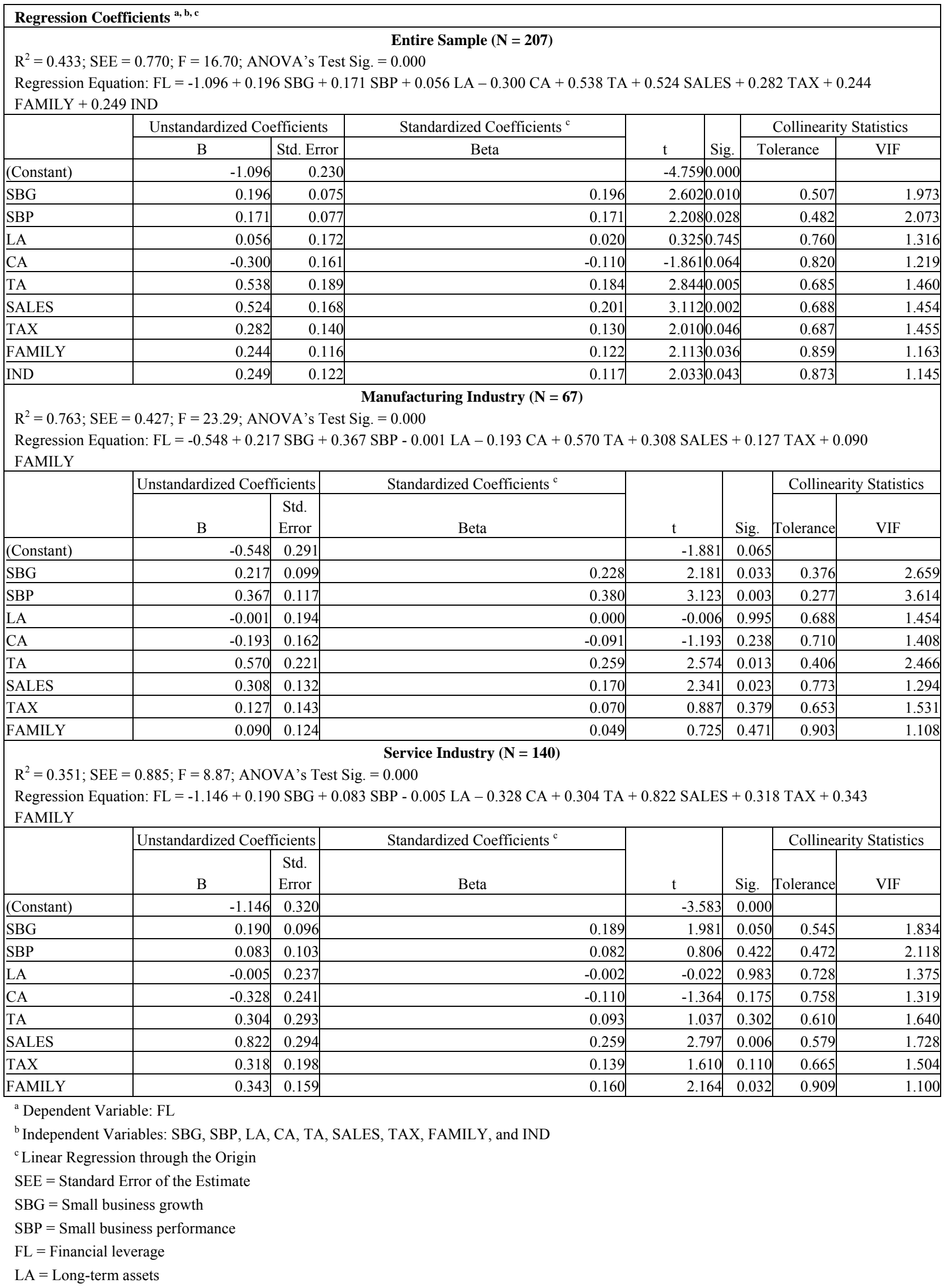




\section{$\mathrm{CA}=$ Current assets \\ $\mathrm{TA}=$ Total assets \\ SALES $=$ Sales \\ TAX $=$ Tax \\ FAMILY $=$ Family \\ IND = Industry}

Table 6.

\begin{tabular}{|c|c|c|}
\hline \multicolumn{3}{|c|}{ Previous Findings Related to Financial Leverage of the Firm } \\
\hline Author & Findings Related to Financial Leverage of the Firm & Country \\
\hline $\begin{array}{l}\text { Michaelas et } \\
\text { al. (1999) }\end{array}$ & $\begin{array}{l}\text { Found positive relationships between i) non-debt tax shield and long-term debt, ii) firm growth and } \\
\text { debt, iii) asset structure and debt, and iv) firm size and debt. Authors also found that level of debt is } \\
\text { negatively correlated with profitability. }\end{array}$ & UK \\
\hline $\begin{array}{l}\text { Gordon and } \\
\text { Lee (1999) }\end{array}$ & Found that taxes have a strong effect on debt levels of small firms. & USA \\
\hline $\begin{array}{l}\text { Esperanca et } \\
\text { al. (2003) }\end{array}$ & $\begin{array}{l}\text { Found that leverage is positively related to i) firm size, asset composition, and firm growth and ii) } \\
\text { negatively related to firm's profitability. }\end{array}$ & Portugal \\
\hline $\begin{array}{l}\text { Huang and } \\
\text { Song (2006) }\end{array}$ & $\begin{array}{l}\text { Found that leverage increases with firm size, non-debt tax shields and fixed assets, and decreases with } \\
\text { profitability. }\end{array}$ & China \\
\hline $\begin{array}{l}\text { Sayilgan et al. } \\
(2006)\end{array}$ & $\begin{array}{l}\text { Found that leverage ratio is i) positively related to firm size and firm growth and ii) negatively related } \\
\text { to profitability and non-tax debt shield. }\end{array}$ & Turkey \\
\hline $\begin{array}{l}\text { Eldomiaty } \\
(2007)\end{array}$ & Found a positive relationship between firm growth and debt. & Egypt \\
\hline $\begin{array}{l}\text { Gill et al. } \\
(2009)\end{array}$ & Found that leverage is negatively correlated with collateralized assets and firm's profitability. & USA \\
\hline $\begin{array}{l}\text { Gill and Mthur } \\
\text { (2011) }\end{array}$ & $\begin{array}{l}\text { Found that financial leverage is i) positively affected by firm size and ii) negatively affected by } \\
\text { collateralized assets, effective tax rate, firm performance, and firm growth. }\end{array}$ & Canada \\
\hline
\end{tabular}

